MIDPI sciforum
MOL2NET, International Conference Series on Multidisciplinary Sciences

Conference on Molecular, Biomedical, and Computational Sciences and Engineering, 7th ed.

\title{
Is citral's anti-inflammatory action capable of changing the hypothalamic inflammation in obese mice?
}

Priscila Romano Raimundo ${ }^{a}$, Vinícius Peixoto Rodrigues ${ }^{a}$, Maycon Tavares EmílioSilva $^{a}$, Gabriela Bueno ${ }^{a}$, Victoria Gabrielle Gomes ${ }^{a}$, Lúcia Regina Machado da Rocha a, Clélia Akiko Hiruma-Lima ${ }^{a}$.

${ }^{a}$ Department of Structural and Functional Biology (Physiology), Institute of Biosciences, São Paulo State University, Botucatu 18618970, São Paulo, Brazil.

\begin{tabular}{|l|l|} 
Graphical Abstract & $\begin{array}{l}\text { Abstract. } \\
\text { Obesity is linked to an inflammatory process in the } \\
\text { different tissues of the body, including hypothalamic } \\
\text { regions that are crucial for energy homeostasis. Citral, } \\
\text { is a monoterpene with anti-inflammatory, antioxidant } \\
\text { and other activities. The aim of the present study was } \\
\text { to evaluate the effect of citral on hypothalamic } \\
\text { inflammation triggered by obesity in male Swiss mice, } \\
\text { and to determine the effect of citral on the } \\
\text { concentration of pro-inflammatory mediators in the } \\
\text { tissue. Obese male Swiss mice were treated orally with } \\
\text { citral (25, 100 and 300 mg/kg) for seven, 14 and 21 } \\
\text { consecutive days. Hypothalamus samples were used } \\
\text { to determine cytokines IL-1 } 3 \text { TNF-a, IL-6. } \\
\text { Hypothalamic inflammation was not installed in the } \\
\text { Swiss mice. There are different studies that report the } \\
\text { anti-inflammatory action of citral, as well as its action } \\
\text { on the body weight of obese mice, however C57BL/6J } \\
\text { mice have a better profile in the investigation of } \\
\text { indicative parameters of diet-induced obesity. An } \\
\text { analysis of the action of citral on hypothalamic } \\
\text { inflammation and evolution of body weight in other } \\
\text { strain, like C57BL/6J mice is relevant. }\end{array}$ \\
expenditure
\end{tabular}




\section{Introduction}

The high rate of obesity is a problem that affects people in Brazil and throughout the world. Obesity is linked to an inflammatory process in the different tissues of the body, including hypothalamic regions that are crucial for energy homeostasis. Therefore, a search for a therapy that modulates the neural machinery is an interesting strategy for the treatment of obesity. An important potential therapeutic alternative is citral, a monoterpene which is the major component of essential oils, like lemon grass (Cymbopogon citratus) and ginger (Zingiber officinale), with antiinflammatory, antioxidant and other activities. Thus, the aim of the present study was to evaluate the effect of citral on hypothalamic inflammation triggered by obesity in male Swiss mice, and to determine the effect of citral on the concentration of pro-inflammatory mediators in the tissue.

\section{Materials and Methods}

Obesity was induced in male Swiss mice $(n=10)$ for 12 weeks on a high-fat diet $(60 \%$ calories from fat). Citral treatment was administered orally in mice at doses of 25,100 and $300 \mathrm{mg} / \mathrm{kg}$ for seven, 14 and 21 consecutive days. Hypothalamus samples were used to determine cytokines IL-1 $\beta$, TNF- $\alpha$, IL- 6 through Luminex multiplex assays. The quantified data are presented as the mean \pm S.E.M. Parametric data was calculated using Student's t-test and one way ANOVA followed by Bonferroni test, the results were considered statistically significant at $p<$ 0,05. All experiments were approved by Animal Ethics Committee (AECs), Institute of Biosciences - UNESP, Botucatu under protocol no 1115 .

\section{Results and Discussion}

Our results have shown that hypothalamic inflammation was not installed in the Swiss mice, and it is not possible to analyze an action of the citral on the pro-inflammatory cytokines. In the literature, there are different studies that report the anti-inflammatory action of citral, as well as its action on the body weight of obese mice, however other experimental protocols have been used. C57BL/6J mice have a better profile in the investigation of indicative parameters of diet-induced obesity.

\section{Conclusions}

An analysis of the action of citral on hypothalamic inflammation and evolution of body weight in other strain, like C57BL/6J mice is relevant.

\section{References}

1. Brasil. Ministério da Saúde. (2017). Vigitel Brasil 2016.

2. Gregor, M.F.; Hotamisligil, G.S. (2011). Inflammatory Mechanisms in Obesity. Annu. Rev. Immunol. 29, 415-445. https://doi.org/10.1146/annurev-immunol-031210-101322.

3. Martins, H. B. et al. (2017) 'Anti-inflammatory activity of the essential oil citral in experimental infection with staphylococcus aureus in a model air pouch', Evidence-based Complementary and Alternative Medicine, 2017. doi: $10.1155 / 2017 / 2505610$.

4. Nishijima, C.M. et al., (2014). Citral: A monoterpene with prophylactic and therapeutic anti-nociceptive effects in experimental models of acute and chronic pain. Eur. J. Pharmacol. 736, 16-25. https://doi.org/10.1016/i.ejphar.2014.04.029.

5. Rishton, G.M., (2008). Natural Products as a Robust Source of New Drugs and Drug Leads: Past Successes and Present Day Issues. Am. J. Cardiol. 101. https://doi.org/10.1016/j.amjcard.2008.02.007.

6. Song, Y. et al. (2016) 'Effects of Citral on Lipopolysaccharide-Induced Inflammation in Human Umbilical Vein Endothelial Cells', Inflammation, 39(2), pp. 663-671. doi: 10.1007/s10753-015-0292-0.

7. WHO, W.H.O., (2018). Obesity and overweight. 